Accepted Manuscript.

Book chapter (https://www.taylorfrancis.com/books/e/9780815354260/chapters/10.4324/9780815354260-

$\underline{45})$ published in "The Routledge Handbook of Memory and Place" (https://doi.org/10.4324/9780815354260),

Routledge, 5/09/2019.

\title{
Ritually Recycling the Landscape
}

\section{Introduction}

British landscapes have long been the stage for ritual. From the enigmatic stone circles of prehistory to the coins we toss into fountains today, a sense of the ceremonial has permeated our environments for millennia. But, as demonstrated throughout this volume, these environments are not static. The landscape is subject to the same mercuriality as the societies inhabiting it. Ritual spaces shift and alter; especially natural sites which, subject to organic processes, undergo constant changes of growth, decay, and destruction, often in defiance of humanity's best efforts to retain continuity.

Just as landscapes are mutable and malleable, so too are rituals. 'Old rituals die hard', writes archaeologist Ralph Merrifield. 'If something has always been done, it may be safer to continue to do it, though it may on occasion be necessary to find a new explanation to reconcile it with the beliefs that are currently acceptable' (1987: 107). A person can observe the essential elements of a ritual, but for it to be relevant to them it must prove malleable enough for the participants to shape and colour it to their liking (Bascom 1965: 29). Indeed, malleability is integral to a ritual's perpetuity. Like all things, rituals must adapt if they are to survive, and in a society of rapidly shifting popular beliefs, rituals must, by necessity, adapt quickly or risk extinction.

This paper demonstrates how even seemingly isolated landscapes can be beset by cultural and environmental changes. Drawing on a particularly remote case-study from the Scottish Highlands, it explores how such landscapes are adapted to accommodate changing rituals, and vice versa; how rituals are adjusted to fit within altered environments. These are the processes of ritual recycling, which I have previously applied to objects, in exploring how a 
mundane item can become sacred by reaching the end of one stage in its biography and entering the next (Houlbrook 2013). However, ritual recycling is a term that can also apply to a landscape, which is reformed into something new by the ritual activities of those who use it.

\section{A Brief History of Excavating the Palimpsest}

Ritually recycling is only one of the many metaphors used to express these processes. It has long been recognised that landscapes, and our cultural perceptions of them, are mutable. Their biographies are complex, non-linear, and inalienable to the biography of society. In scholarship, this characteristic has come to be viewed as more than an incidental aspect of the landscape, but as the crux of our understanding of it. A prime example is Keith Thomas's Man and the Natural World (1983), a diachronic exploration of the shifting perspectives of British society towards their trees and woodland. In his chapter on 'The Worship of Trees' (1983: 212-223), Thomas describes how woodlands were increasingly imbued with symbolic value in the early modern period. From the eighteenth century onwards, they became emblematic of a community's continuity, of the nation's strength, and of a family's ancestry. Such meanings were not inherent to these landscapes; they were endowed by society.

Since archaeologist Osbert Crawford first applied the palimpsest metaphor to the 'surface of England', as a 'document that has been written on and erased over and over again', historians, archaeologists, and geographers alike have been employing a variety of imagery to illustrate the complex nature of our relationship with the natural environment (1953: 51). In the 1950s, William Hoskins was advocating the study of landscape 'as though it were a piece of music, or a series of compositions of varying magnitude, in order that we may understand the logic that lies behind the beautiful whole' (1955: 20). In the 1970s, geographer Donald 
Accepted Manuscript.

Book chapter (https://www.taylorfrancis.com/books/e/9780815354260/chapters/10.4324/9780815354260-

$\underline{45}$ ) published in "The Routledge Handbook of Memory and Place" (https://doi.org/10.4324/9780815354260), Routledge, 5/09/2019.

Meinig was describing the landscape as an 'accumulation....an enormously rich store of data about the peoples and societies which have created it' (1979: 44). And in the 1980s, Oliver Rackham was expressing the landscape as a library, in a detailed analogy that deserves to be repeated in full:

The landscape is like a historic library of 50,000 books. Many were written in remote antiquity in languages which have only lately been deciphered; some of the languages are still unknown. Every year fifty volumes are unavoidably eaten by bookworms.

Every year a thousand volumes are taken at random by people who cannot read them, and sold for the value of the parchment. A thousand more are restored by amateur bookbinders who discard the ancient bindings, trim off the margins, and throw away leaves that they consider damaged or indecent. The gaps in the shelves are filled either with bad paperback novels or with handsomely-printed pamphlets containing meaningless jumbles of letters. The library trustees, reproached with neglecting their heritage, reply that Conservation doesn't mean Preservation, that they wrote the books in the first place, and that none of them are older than the eighteenth century; concluding with a plea for more funds to buy two thousand novels next year. (1986: 2930)

Here the landscape is portrayed as a perpetually changing environment, with aspects being lost and others introduced in an inevitable narrative of revisions and transitions.

Another analogy drawn on is Simon Schama's description of how the landscape is built up from strata of myth and memory lying beneath the surface - strata to be excavated - in his almost poetic ode to Landscape and Memory (1995: 7). While Alexandra Walsham, in her seminal biographical treatment of The Reformation of the Landscape, traces the changing perceptions of the religious landscape throughout the early modern period by presenting the 
natural environment as 'a porous surface upon which each generation inscribes its own values and preoccupations without ever being able to erase entirely those of the preceding one' (2011: 6).

The term 'ritual recycling' encapsulates all the above observations. It describes a site, a monument, a whole landscape that is being adapted to fulfil a certain ceremonial purpose. Physically the recycled landscape might be the same, or the changes do not quite conceal past uses - like an under-layer of Crawford's palimpsest - but it has been restructured to fulfil a different purpose. Landscapes are old and new at the same time. The base material remains largely constant but its uses can be in constant flux. To illustrate this process, I have drawn on the complex ritual narrative of a small and remote landscape in the Scottish Highlands: Isle Maree.

\section{Introducing Isle Maree}

Stretching for twelve miles in a north-westerly direction, Loch Maree in Wester Ross is the fourth largest fresh-water loch in Scotland, and accommodates more than sixty islands. One of these islands shares its name with the loch. Situated 250 metres from the northern shore, Isle Maree is of triangular shape and covers six acres, making it one of the smaller islands. However, despite its modest size, it is seen as Loch Maree's 'principal island' (Reeves 185760: 268), and it is a landscape that boasts a long narrative of ritual recycling.

Ecologically, it is one of the more interesting islands on the loch, with its densely forested centre. In the eighteenth century, traveller and antiquarian Thomas Pennant described it as 'the most beautiful of the isles; the others have only a few trees sprinkled over their surface', whilst Isle Maree was richly adorned with oak, ash, birch, willow, hazel, and holly (1775: 
330). Anthropologist Gertrude Godden, visiting the island over a century later, describes it with equal admiration: 'so covered with luxuriant foliage that a fragment of green forest seems to have been carved out and placed in the loch, set in a border of golden sand' (1893: 498).

Both the island and the loch are named after the area's patron saint, St. Maelrubha (also known as Maree). Born in County Down, Ireland, in 642, St. Maelrubha came to Scotland and founded the monastic community of Applecross, Ross, in 673 (Reeves 1857-60: 259; Mitchell 1863: 254-255). He is often credited with the introduction of Christianity into this region of Scotland and, following his death in 722 , he became the patron saint of the district (Mitchell 1863: 254-255).

Isle Maree was purportedly the saint's 'favoured isle' and, according to popular belief, it became the site of his chapel (Pennant 1775: 330). Why he chose this particular island over the many others remains a mystery, but it was possibly a case of ritual recycling. There is a theory that the saint was supplanting an earlier pagan centre, a well-known method of Christianisation. Pennant describes the remains of a structure at the island's centre, consisting of a circular dike of stones with a narrow entrance, which Pennant believed 'to have been originally Druidical, and that the ancient superstition of Paganism had been taken up by the saint, as the readiest method of making a conquest over the minds of the inhabitants' (1775: 330, emphases in original). However, evidence of a structure is not evidence of paganism. Whatever was there could have post-dated St. Maelrubha.

However, the island's profusion of oak trees (traditionally associated with Druids) has also been cited as possible evidence that the island was a pagan cultic centre before St. Maelrubha's arrival, and it is popularly claimed that the saint planted holly on the island, a 
Accepted Manuscript.

Book chapter (https://www.taylorfrancis.com/books/e/9780815354260/chapters/10.4324/9780815354260-

$\underline{45})$ published in "The Routledge Handbook of Memory and Place” (https://doi.org/10.4324/9780815354260), Routledge, 5/09/2019.

tree with Christian connotations, to counterbalance the more pagan oak. There is no way to prove or disprove this, but if it was the case then this is a prime example of ritually recycling the landscape: subtle alterations to the natural environment reflecting changes in how and by whom the site is used.

\section{The Holy Well of Isle Maree}

The same process of ritual recycling was applied to the island's well, which sits in the southwest corner of the island. Believed to have been consecrated by St. Maelrubha, this water source became a 'holy well', widely held in the surrounding districts to cure lunacy. Many pilgrims were said to have visited the island (sometimes of their own volition but often in custody) and drank from the well in order to affect a cure for mental illness (Pennant 1775: 330; Reeves 1857-60: 288-289; Mitchell 1863: 251-262; Queen Victoria (Duff 1968: 332); Dixon 1886: 151; Godden 1893: 500-501; Muddock 1898: 437-438; Barnett 1930: 113). This well may be further equivocal evidence that the site possessed some pre-Christian significance. Many of the wells that dot the British landscape are believed to have originally been employed as part of pagan hydrolatry, but they were later adopted by Christianity, the wells transferring to the guardianship of Christian saints (Daly 1961; Rattue 1995).

Under St. Maelrubha's custodianship, the well's perceived powers appear to have lasted centuries, surviving the Scottish Reformation and stretching into the Victorian period. It was probably last resorted to for the cure of insanity in the 1850s. Godden dates the last appeal to the holy well to 1857 (1893: 500), while John Dixon cites an example from 1858 of a woman from Easter Ross having been taken to the island for a cure (1886: 151). Certainly by this time, however, belief in the well had waned - possibly following the desecrating act of a 
Accepted Manuscript.

Book chapter (https://www.taylorfrancis.com/books/e/9780815354260/chapters/10.4324/9780815354260-

$\underline{45})$ published in "The Routledge Handbook of Memory and Place” (https://doi.org/10.4324/9780815354260),

Routledge, 5/09/2019.

farmer lowering his afflicted dog into the well earlier that century. And by the time Arthur Mitchell, physician and historian, visited Isle Maree in 1863, the well was dry 'and full of last year's leaves, and the flat stone which serves for a cover we found lying on the bank' (1863: 262).

By the 1950s, when travel writer Brenda Macrow visited the island, she remarked on how difficult it was to determine the site of this well (1953: 88). It is unknown whether the well was filled up deliberately, having purportedly lost its efficacy, or whether this was simply the result of many years of disuse. Either way, no visible trace remains of either the well or its stone slab covering today. The well was not, however, the last feature in this landscape to have been ritually employed.

In Pennant's 1775 description of the island, he writes of how pilgrims would drink from the holy well and then leave an offering to the saint on a nearby tree stump, which he describes as 'an altar, probably the memorial of one of stone' (1775: 330). The landscape has been ritually recycled once more: a tree has been transformed into a votive altar, possibly replacing a stone predecessor. The tree does not seem to have been significant in itself; more for its convenient location. Trees that stood beside holy wells were often used as receptacles for offerings. John Campbell writes of a similar arrangement on the Hebridean island of Islay, where votive objects, such as copper caps, pins, and buttons, were 'placed in chinks in rocks and trees at the edge of the "Witches' Well"' (1860: 134).

However, in many cases, a tree connected with a holy well is not incidental, but central to the ritual itself. Trees can become sacred via osmotic transference; their association with the holy wells bestows sanctity upon them also (McPherson 1929: 74; Lucas 1963: 40). This bestowal may be literal as well as symbolic, with the holy water from the well travelling into the tree 
Accepted Manuscript.

Book chapter (https://www.taylorfrancis.com/books/e/9780815354260/chapters/10.4324/9780815354260-

$\underline{45})$ published in "The Routledge Handbook of Memory and Place” (https://doi.org/10.4324/9780815354260), Routledge, 5/09/2019.

itself (Shephard 1994: 2). At St Patrick's Well, Enfield, Co. Westmeath, for example, the water which emerges from between the roots of an ash tree is believed to cure eye disease, while at Easter Rarichie, Ross and Cromarty, the healing spring known as Sul na Ba flowed through a tree trunk, endowing that tree with curative properties itself (Bord and Bord 1985: 59; Milner 1992: 139). It is not uncommon for a tree to replace desecrated or polluted holy wells as the objects of people's veneration, thus becoming 'holy wells' themselves. ${ }^{\text {i }}$

This transference of sanctity not only imbues the tree with power, but allows it to establish itself as a ritual structure independent from the holy well, so that it may subsequently outlive it. For example, the holy well on the River Sullane, Ireland, had run dry by the early twentieth century, but the surrounding briar bushes were still heavily affixed with votive offerings (Hull 1928: 108). The same process occurred on Isle Maree: the tree outlived the well. Visiting the site in the 1920s, lieutenant colonel George Edington in fact wrote that the tree had 'been fixed into the filled-up holy well' (cited in McPherson 1929: 75), revealing that the tree had replaced the well physically as well as ritually. While this tree may have originally been ritually recycled simply because of its association with the holy well, it went on to supplant that well.

\section{The Tree of Isle Maree}

When Pennant described the tree in 1775 , he did not specify what form of objects the pilgrims deposited. Later sources, however, refer to its use as a rag-tree. Hartland describes how pilgrims, seeking a cure from the holy well of St. Maelrubha, attached pieces of clothing to the nearby tree (1893: 453), and Barnett reports that the patients brought to the island would tie rags or ribbons to its branches (1930: 114). On Mitchell's visit to Isle Maree in 
Accepted Manuscript.

Book chapter (https://www.taylorfrancis.com/books/e/9780815354260/chapters/10.4324/9780815354260-

$\underline{45})$ published in "The Routledge Handbook of Memory and Place" (https://doi.org/10.4324/9780815354260), Routledge, 5/09/2019.

1863, the tree was apparently studded with nails: 'To each of these was originally attached a piece of the clothing of some patient who had visited the spot' $(1863: 253)$. This use of rags corresponds with the connection of Isle Maree to the cure of insanity. In the British Isles, ragtrees were most commonly employed to affect cures. It was widely believed that rags contained whatever ailment the depositor wished to be rid, and by affixing them to a tree, the ailment is transferred from person to tree via 'contagious transfer' (Hartland 1893: 460; Frazer 1900: 39; Foley 2010, 2011).

However, at some point during its ritual career, the tree on Isle Maree shed its rags and ribbons and became predominantly a nail-tree. Mitchell describes how the tree was 'studded with nails' (1863: 253), whilst Hartland observes how 'Many of the nails are believed to be covered with the bark, which appears to be growing over them' (1893: 453-454). This reincarnation as a nail-tree is a logical next evolutionary step from the rag-tree; pins and nails were particularly popular devices for contagious transfer. Knocking nails into an oak tree, for example, was a well-known remedy for toothache in Cornwall. The toothache was believed to transfer into the tree, from the sufferer, through the nail (Walhouse 1880: 99n; Porteous 1928: 188). Pins were also employed as cures for warts; inserted into each wart, then into the bark of an ash tree, this was believed to transfer the affliction to the tree (Wilks 1972: 121). It may not only have been the physical properties of nails, permitting easy insertion, that gave these objects such perceived powers, but also their association with the crucifixion and thus their history of ritual significance within Christianity (cf. Hutton 1998: 108).

The transformation of the rag-tree into a nail-tree, however, was probably wholly incidental. As has been observed, the rags and ribbons were attached to the tree using nails (Mitchell 1863: 253; Hartland 1893: 453). The nails were therefore convenient tools for securing 
Accepted Manuscript.

Book chapter (https://www.taylorfrancis.com/books/e/9780815354260/chapters/10.4324/9780815354260-

$\underline{45})$ published in "The Routledge Handbook of Memory and Place” (https://doi.org/10.4324/9780815354260),

Routledge, 5/09/2019.

offerings, rather than offerings themselves. However, cloth decomposes much faster than iron; the nails would therefore survive long after the rags and ribbons had decayed. This natural process, leaving the tree studded with nails rather than adorned with rags, likely led to its gradual transformation into a nail-tree. Pilgrims to the island began inserting nails as votive offerings or vehicles of contagious transfer in and of themselves.

\section{The Coin-Tree}

The tree on Isle Maree did not remain a nail-tree for long. In 1877 the island's reputation warranted it a visit from Queen Victoria, whose tour of Scotland had led her to the loch. Writing in her diary, Queen Victoria described the tree, and how it had become the custom 'for everyone who goes there to insert with a hammer a copper coin, as a sort of offering to the saint' (Duff 1963: 332). The tree had become a coin-tree. Indeed, by the 1890s, it was being referred to as 'the money tree' (Muddock 1898: 437), and by Colonel Edington's visit in 1927, no pins or nails were visible in the bark of the tree, only coins (McPherson 1929: 75) - so many coins, in fact, that Edington describes the tree as 'covered with metallic scales...something like what is depicted on a dragon' (cited in McPherson 1929: 75).

The hundreds of coins inserted into clefts and cracks have no doubt taken their toll on this tree, which is now dead. McPherson writes that this 'holy tree shared the fate of the holy well - the devotion of pilgrims has proven its undoing. The coins, hammered in and destroying the bark, have killed the object of their veneration' (1929: 75). The death of the tree, however, has not led to the death of the tradition. Indeed, it appears to have proliferated. As the original tree became too densely coined, the custom appears to have spread to surrounding trees. 
Accepted Manuscript.

Book chapter (https://www.taylorfrancis.com/books/e/9780815354260/chapters/10.4324/9780815354260-

45) published in "The Routledge Handbook of Memory and Place" (https://doi.org/10.4324/9780815354260),

Routledge, 5/09/2019.

By the 1950s, people had begun inserting coins into the stake used to prop up the original tree as well as into the barks of surrounding trees (Macrow 1953: 88-89). In 2002, when the North of Scotland Archaeological Society conducted a survey of the site, they observed that the original coin-tree (referred to in their report as a votive tree, and catalogued as VT1) was leaning on six spars, also embedded with coins, and counted two subsidiary parts of VT1, scattered some distance away, VT2 and VT3 (North of Scotland Archaeology Society 2002: 22-23). In total, they catalogued nine boles and spars embedded with coins on Isle Maree.

In the intervening decade between the 2002 survey and my own fieldwork, on $14^{\text {th }}$ April 2012, this number had further increased. Clustered around what is believed to have been the original tree are twelve further spars, logs, stumps, and living trees that have been embedded with coins. I counted approximately 2000 coins, although this probably only represents the tip of the iceberg: many coins had fallen from the decaying trees and become buried over time. The majority of the coins were decimal one pennies, half pennies, and shillings, and while most of the years of issue had long since become illegible, I was able to date one to 1875. Surprisingly, however, there were also many coins that were post-decimalisation, the most recent one dating to 2010 . There was also some foreign coinage, including a Dutch fiveguilder coin from 1985, ten Dutch cents, a one Euro cent, and a one US cent. The custom of leaving an offering in this landscape has far from fallen out of popularity, even in the twentyfirst century (Houlbrook 2014, 2015a, 2015b, 2018).

\section{The Wishing-Tree}

The custom is, however, no longer observed for affecting cures. By the time the tree had become a coin-tree in the late nineteenth century, its purpose had changed. It had become a 
'wishing-tree'. ii It was now believed that, as described by McPherson, a 'wish silently formed when any metal article was attached to the tree, or coin driven in, would certainly be realised' (1929: 76). No longer associated with healing, the tree became imbued with the power to grant wishes or to ensure good luck (MacLeish 1968: 420), the only two traditions which participants seem to observe today. Local residents in Gairloch, for example, associate the tree with only two things: wish-making and good luck. The tree has therefore shed its (Christianised) curative properties and become a wishing-tree instead, a custom much more inclusive - albeit perhaps less earnestly observed.

Whether or not all of the stories told about Isle Maree are grounded in historical truth, the landscape of this island has a long narrative of ritual recycling within the popular imagination. With the rise of Christianity, Isle Maree's possible pagan associations were supplanted by St. Maelrubha, who was believed to have sanctified the island and consecrated the well. Isle Maree thus became Christianised, and for centuries it was a destination for pilgrims hoping to affect cures. However, believed to be polluted by the farmer's dog, the well fell out of use and was filled in - to be replaced, both symbolically and literally, by the tree, which was used as a receptacle for offerings and devices of contagious transfer: rags, nails, and then coins. However, with the declining faith in the power of saints and folk-cures, the tradition needed to adapt to retain its popularity. And so, ritually recycled once more, Isle Maree became the site of a modern-day wishing-tree, demonstrating that even an island is not an island in the metaphorical sense of detached seclusion. It can sustain a sense of the sacred but can never be isolated from external changes and events.

\section{Future Directions}


In 1955, Hoskins lamented that, 'especially since the year 1914, every single change in the English landscape has either uglified it or destroyed its meaning, or both' (1955: 238).

Rackham was less direct in his condemnation of contemporary changes, but his disapproval is still clear: the older volumes in the metaphorical landscape have been lost or taken, and the 'gaps in the shelves are filled either with bad paperback novels or with handsomely-printed pamphlets containing meaningless jumbles of letters' (1986: 30). Thankfully, perceptions have moved on, and the contemporary changes in our landscapes are no longer being dismissed as irrelevant to their narratives. Instead, they are recognised as the latest set of words inscribed on the palimpsest; as the topmost layer in the strata of myth and memory. As the most recent recycled state.

Where might this topic go from here? As with the ritually recycled landscape, while it is impossible to predict with any certainty what its future state will be, it will no doubt continue to adapt. Because our environments and our beliefs will never stop changing, the subject is unlikely to dry up. Natural spaces will continue to be used as sacred places, even if what constitutes 'sacred' is likely to change - and even if what constitutes 'natural' is also likely to change. For this topic to be adequately explored, a wide chronological scope is required. Historians and archaeologists will need to engage with ethnographic material to understand how the sites they study have been ritually recycled in the present. Likewise, anthropologists exploring contemporary sacred landscapes will need to trace the histories of their sites, in order to appreciate their ritual narratives. Only by adopting a broad and inclusive scope, as well as a variety of methodologies, will we be able to fully comprehend the extent to which our landscapes have been, and will continue to be, ritually recycled. 
Accepted Manuscript.

Book chapter (https://www.taylorfrancis.com/books/e/9780815354260/chapters/10.4324/9780815354260-

45) published in "The Routledge Handbook of Memory and Place" (https://doi.org/10.4324/9780815354260), Routledge, 5/09/2019.

${ }^{i}$ In his catalogue of the sacred trees of Ireland, Lucas lists numerous examples: Lady's Well, Skirk, Co. Laois; The Tree of Castlebellew, Cloonoran, Co. Galway; the Pin Well, Tartaraghan, Co.

Armagh; Mary's Well, Rockspring, Co. Cork; and St. Margaret's Well, Cooraclare, Co. Clare (1963: 41)

ii 'Wishing tree' is a term employed by Dixon (1886: 150), Godden (1893: 499), McPherson (1929: 76), Barnett (1930: 114), and Macrow (1953: 88-89) to describe the Isle Maree tree. 